\title{
STUDY OF THE HARDNESS \& THE MICROSTRUCTURE OF AISI 1050 MEDIUM CARBON STEEL AFTER HEAT TREATMENT PROCESSES
}

\begin{tabular}{|l|l|}
\hline Sanjeev Kumar Jaiswal & T.Sharma \\
Department of Mechanical & Department of Fuel \& \\
Engineering, School of & Mineral Engineering, Indian \\
Engineering \& Technology, & School of Mines, Dhanbad \\
Sharda University, Greater & ,India. \\
Noida (U.P), India & Email ID:- \\
Email ID: - & hodsmeism@yahoo.co.in \\
sanjeevjaiswal62@gmail.com & \\
\hline
\end{tabular}

Abstract: Main Objective is to Study the Effect on the Hardness \& microstructure of Sample Grade of AISI 1050 medium carbon steel. Heat Treatment Processes Such As Annealing, Normalizing, and Hardening is carried on AISI 1050 medium carbon steel \& after treatment aims to perform hardness testing on the treated and untreated work samples. Full annealing is done at $800^{\circ} \mathrm{C}, 825^{\circ} \mathrm{C} \& 850^{\circ} \mathrm{C}$ for soaking time 10 minutes, 15 minutes \& 20 minutes respectively. Sub critical annealing is done at $675^{\circ} \mathrm{C} \mathrm{\&} 700^{\circ} \mathrm{C}$ for soaking time 10 minutes \& 15 minutes respectively.

The present work investigates the effect of cooling on the microstructure and hardness of AISI 1050 Carbon Steel. Sample size with a diameter $20 \mathrm{~mm}$ were heat treated for soaking time of 10 minutes, 15 minutes $\& 20$ minutes at $800^{\circ} \mathrm{C}, 825^{\circ} \mathrm{C} \& 850^{\circ} \mathrm{C}$ respectively and were quenched in three different medium- (1) cold water (2) hot water \& (3) vegetable oil to study the effect of various quenching medium on the hardness of AISI 1050 medium carbon steel.

Keywords: - AISI 1050 Carbon Steel, Annealing, Hardening, Heat Treatment, Normalizing and Quenching Medium.

\section{INTRODUCTION}

Steels have been used since the Iron Age and their importance in the development of the industry have been enormous. Steels are the most important alloys utilized as structural material. They are straightforwardly related to engineering. The Microstructure of most steels is well known by now as well as the effect of heat treatments in changing their mechanical properties [1]. For instance, the hardness of AISI 1050 carbon steel could vary from approximately 20-58 HRC depending on its heat treatment [1]. The differences in mechanical properties of given steel are the result of different microstructure formed during cooling. This statement generally means that the highest hardness in the iron carbon systems is obtained due to a diffusion less

\begin{tabular}{|l|l|} 
Rajesh M. & Vineet Kumar \\
Department of Mechanical & Department of Sharda \\
Engineering & University, \\
Sharda University, Greater & Greater Noida \\
Noida & Email ID:- \\
Email ID:- & vineet.kumar5@sharda.ac.in \\
rajesh.m@ sharda.ac.in & \\
& \\
\hline
\end{tabular}

transformation called marten site formation and lowest hardness is obtained due to a diffusion transformation, which causes the ferrite and /or pearlite formation by a eutectoid reaction. Both marten site obtained during rapid cooling and ferritepearlite obtained during slow cooling or near the equilibrium, come

from austenite [1]. Effect of heat treatment on the mechanical properties for rolled medium carbon steel studies by [2].Similarly, the effect of cooling rate on Hardness and Microstructure of AISI 1020, AISI 1040 and AISI 1060 Steels [3].

\section{MATERIALS AND METHODS}

The chemical composition of AISI 1050 Carbon steel Table 1

\begin{tabular}{|l|l|l|l|l|}
\hline Steel Type & $\mathrm{C}$ & $\mathrm{Mn}$ & $\mathrm{Si}$ & $\mathrm{Fe}$ \\
\hline AISI 1050 & .55 & .65 & .25 & 98.55 \\
\hline
\end{tabular}

The material used in this study is $20 \mathrm{~mm}$ diameter AISI 1050 Carbon Steel. The AISI 1050 steel cut $20 \mathrm{~mm}$ length with the help of power-hexa machine and remove the burr with the help of grinding machine. The samples were heated at $800^{\circ} \mathrm{c}$ for 10 minute to remove the potential residual stresses before micro hardness tests.

The samples were heat treated at $800^{\circ} \mathrm{C}, 825^{\circ} \mathrm{C} \&$ $850^{\circ} \mathrm{C}$ for soaking time 10 minutes, 15 minutes $\& 20$ 
minutes respectively were cooled by three different quenching mediums cold water, hot water \& vegetable oil.

\section{EXPERIMENTAL SETUP}

\section{A.OBJECTIVE}

The objective of the present investigation is to

i. Hardening the surface of medium carbon steel.

ii. Evaluate the change in the hardness of medium carbon steel.

iii. Further harden the medium carbon steel by quenching.

iv. Explore the effects of tempering on hardened steel samples.

v. Explore the effects of soaking time on hardened steel samples.

vi. Analyzing the micro structure of medium carbon steel.

vii. Studying and comparing the change in the hardness after hardening different compositions of steel by different quenching medium.

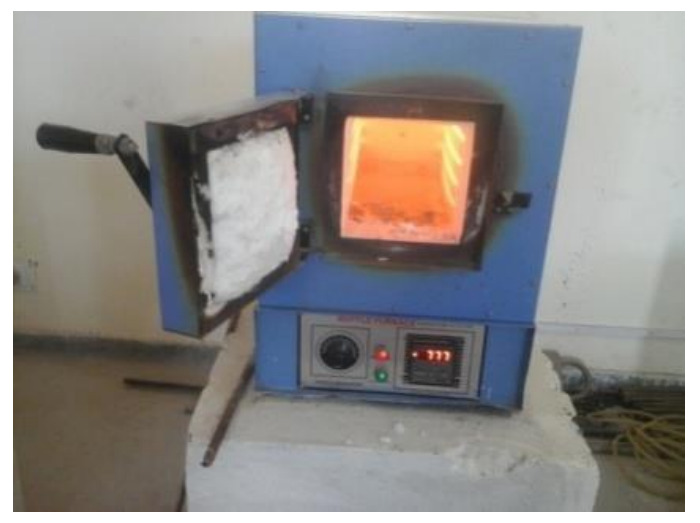

Fig.1 Muffle furnace

\section{B. METHODOLOGY}

i. $\quad$ Take grade AISI 1050 containing C 0.55 \{medium carbon steel\} for preparation of sample with diameter $20 \mathrm{~mm}$.

ii. Preparation of 25 samples of $20 \mathrm{~mm}$ length for heat treatment. \{hardening and tempering \}

iii. Hardening in different medium

a) cold water b) hot water

c) oil

iv. Setup Muffle furnace temperature $800^{\circ} \mathrm{C}, 825^{\circ} \mathrm{C}$ $\& 850^{\circ} \mathrm{C}$

v. Measure hardness before quenching

vi. Measure hardness after quenching

vii. Similarly measure the effect of soaking time in $10,15 \& 20$ minutes

\section{Preparation of samples for hardness testing}

- $\quad$ Take grade AISI 1050 containing C 0.55 $\{$ medium carbon steel $\}$ for preparation of sample with diameter $20 \mathrm{~mm}$.

- $\quad$ Preparation of 25 samples of $20 \mathrm{~mm}$ length for heat treatment. \{ hardening and tempering\}

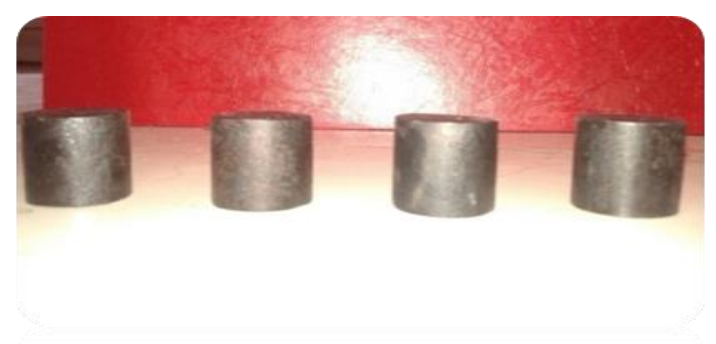

Fig. 2 Samples of AISI 1050 Carbon Steel with diameter $20 \mathrm{~mm}$

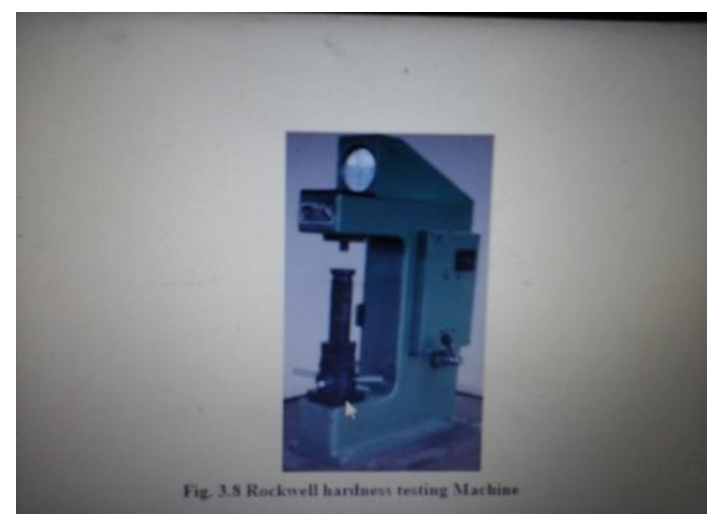

Fig.3 Rockwell Hardness Testing Machine 


\section{(2)}

ELK

Asia Pacific Journals

\section{D.MICROSCOPY STUDY}

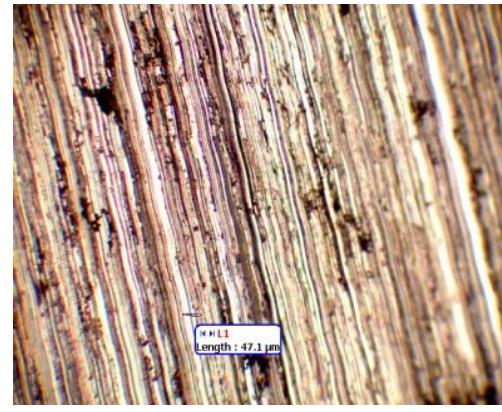

Fig.4 The microstructure of AISI 1050 carbon steel (10X)

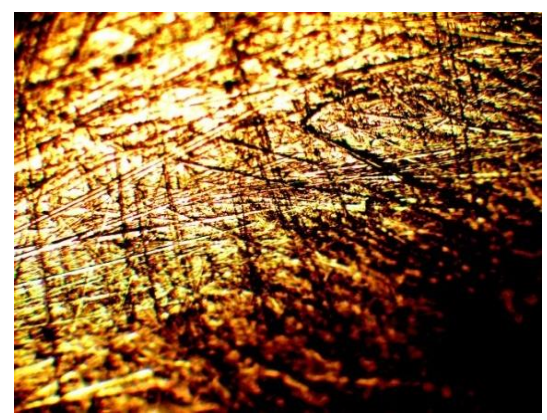

Fig. 5 The microstructure of AISI 1050 BHT (10X)

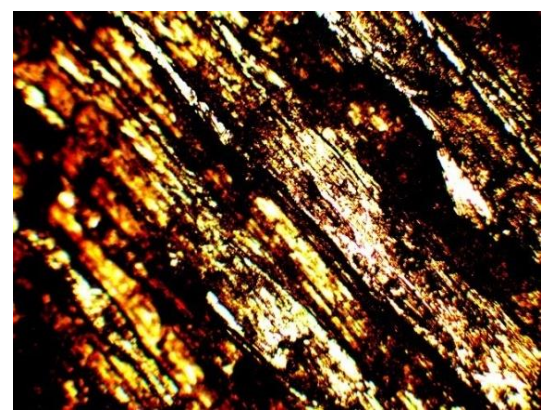

Fig.6 The microstructure of AISI 1050 BHT (10X)
ELK Asia Pacific Journals - Special Issue ISBN: 978-81-930411-4-7

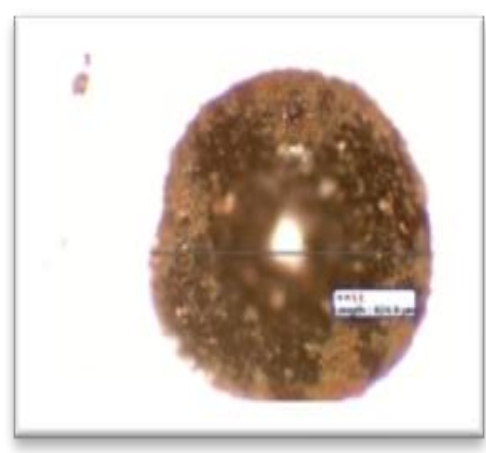

Fig.7 Microstructure of AISI 1050 BHT on Rockwell B (10X)

Based on fig.4, fig.5, fig.6 \& fig7 shows the various microstructure of AISI 1050 Carbon steel before heat treatment

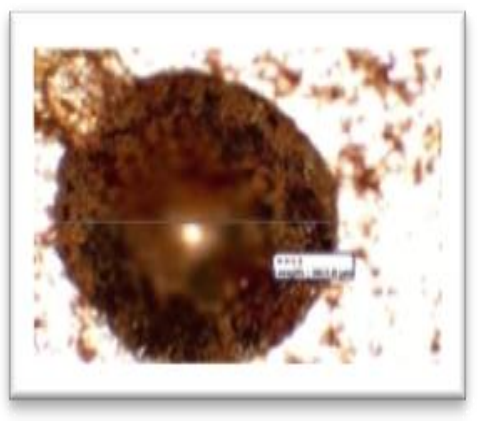

Fig. 8 The microstructure of hardening samples at $800^{\circ} \mathrm{C}$ For cold water for $10 \mathrm{~min}(10 \mathrm{X})$

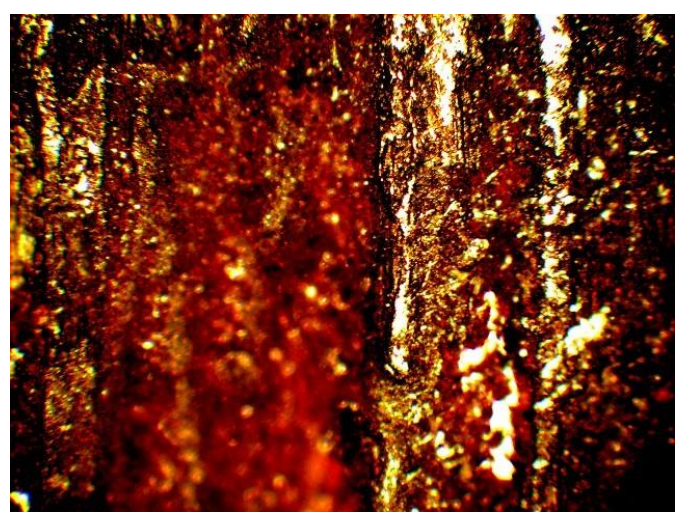

Fig 9 The microstructure of $800^{\circ} \mathrm{c}$ hardening temperature for $10 \mathrm{~min}$ in cold water (10X) 


\section{(a)}

ELK

Asia Pacific Journals

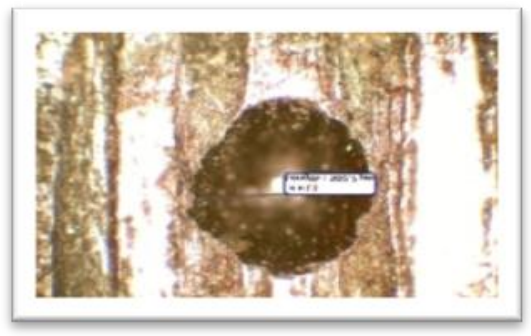

Fig. 10 The microstructure of $800^{\circ} \mathrm{C}$ hardening for 15 min in cold water $(10 \mathrm{X})$

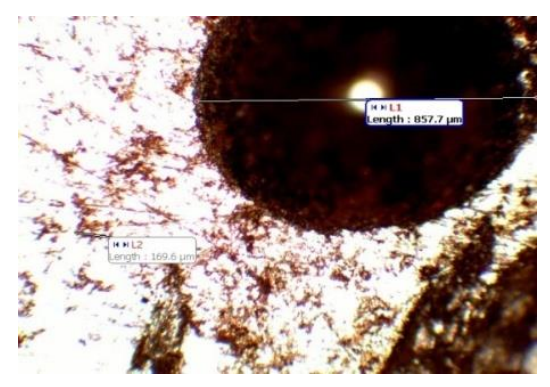

Fig. 11 The microstructure of $850^{\circ} \mathrm{C}$ hardening for 20 min in cold water (10X)

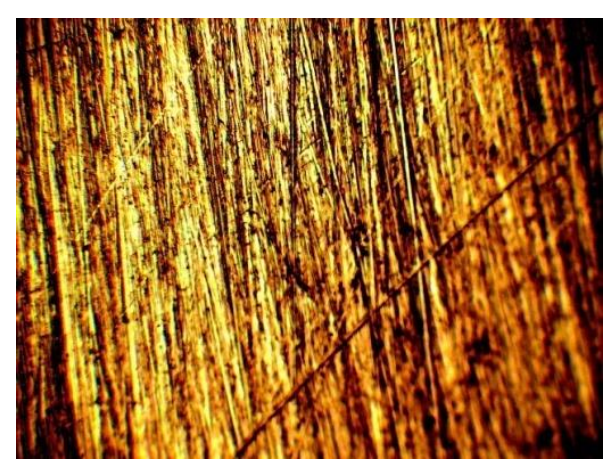

Fig.12The microstructure of AISI 1050 steel at $850^{\circ}$ $\mathrm{C}$ in hot water for $20 \mathrm{~min}(10 \mathrm{X})$

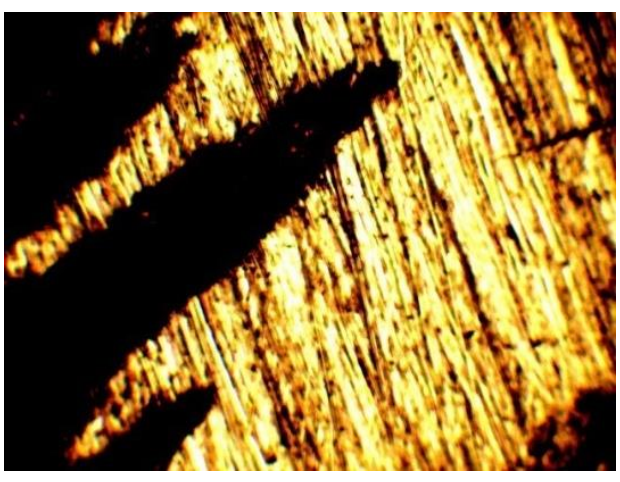

Fig. 13The microstructure of hardening samples at $825^{\circ} \mathrm{C}$ for oil for $15 \mathrm{~min} \operatorname{RHB}(10 \mathrm{X})$

Based on fig8, fig.9, fig.10, fig.11, fig.12\& fig.13 shows the microstructure of AISI 1050 Carbon steel heat treatment conditions for hardening temperature for different soaking time intervals

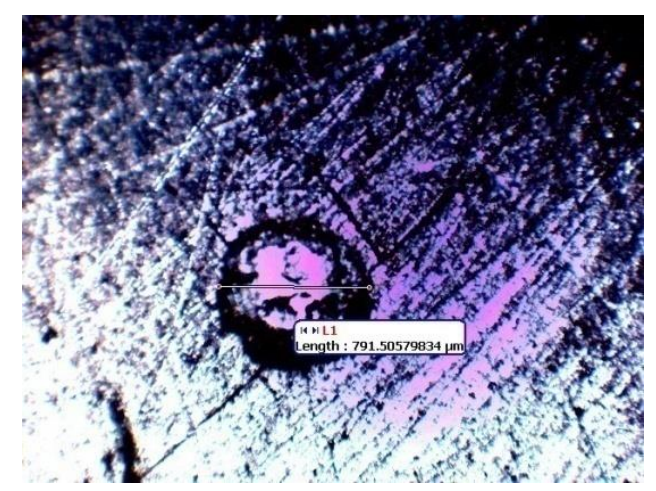

Fig.14 The microstructure of sub critical annealing at $675^{\circ} \mathrm{C}$ for $15 \mathrm{~min}$ RHB (4X)

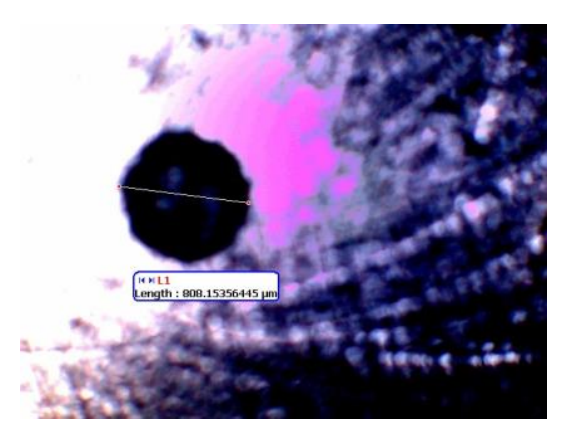

Fig.15 The microstructure of sub critical annealing at $700^{\circ} \mathrm{C}$ for $20 \mathrm{~min} \mathrm{RHB}(4 \mathrm{X})$ 


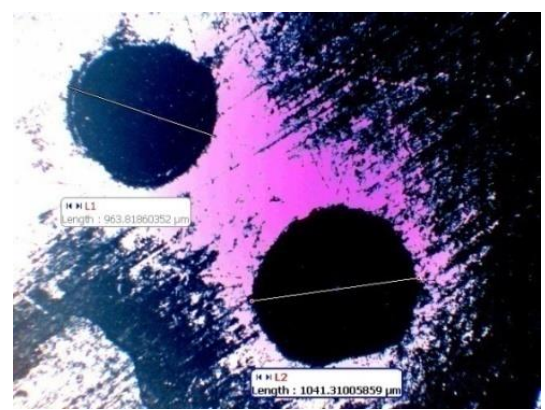

Fig. 16 The microstructure of full annealing at $800^{\circ} \mathrm{C}$ for 10 min RHB (4X)

Based on fig.14, fig. $15 \&$ fig. 16 shows the microstructure of AISI 1050 Carbon steel heat treatment conditions for full annealing \& sub critical annealing

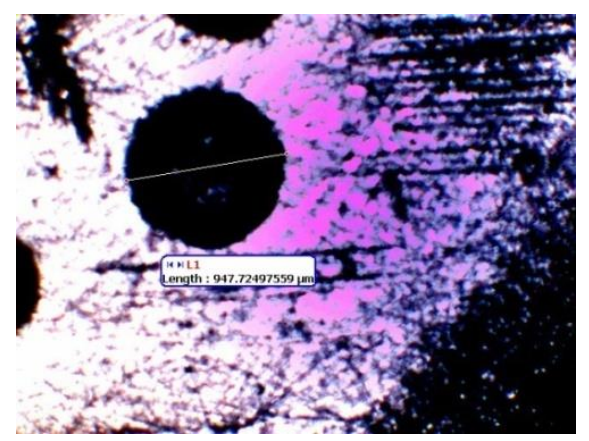

Fig. 17 The microstructure of normalizing samples at $800^{\circ} \mathrm{C}$ for $10 \mathrm{~min}$ RHB (4X)

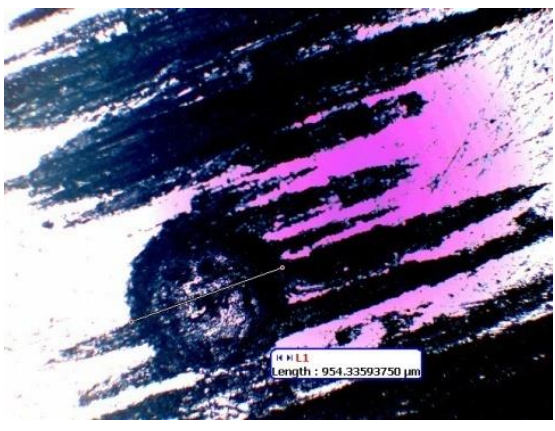

Fig.18 The microstructure of normalizing samples at $825^{\circ} \mathrm{C}$ for $15 \mathrm{~min}$ RHB (4X)

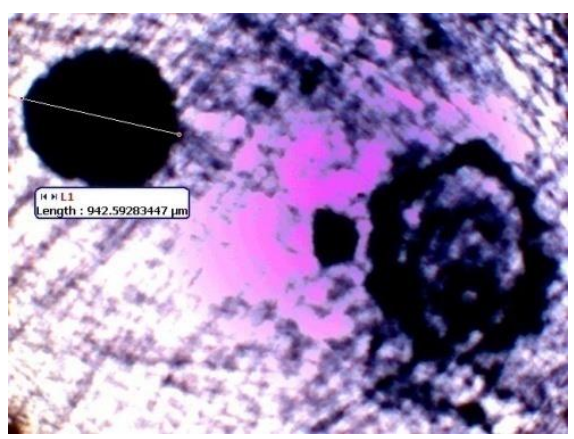

Fig.19 The microstructure of normalizing samples at $850^{\circ} \mathrm{C}$ for 20 min RHB (4X)

Based on fig.17, fig. 18 \& fig. 19 shows the microstructure of AISI 1050 Carbon steel heat treatment conditions for normalizing

\section{Result \& discussion}

Table 2.Heat Treatment conditions for hardening of AISI 1050 Carbon steel-

\begin{tabular}{|c|l|c|c|c|}
\hline $\begin{array}{c}\text { Hardening } \\
\text { Temperature }\end{array}$ & $\begin{array}{l}\text { Quenching } \\
\text { Media }\end{array}$ & $\begin{array}{c}\text { Soaking } \\
\text { Time }\end{array}$ & RHB & RHC \\
\hline $800^{\circ} \mathrm{C}$ & Cold Water & 10 & 93.5 & 58.5 \\
\hline $825^{\circ} \mathrm{C}$ & Cold Water & 10 & 95.5 & 60.86 \\
\hline $850^{\circ} \mathrm{C}$ & Cold Water & 10 & 98 & 62.17 \\
\hline $800^{\circ} \mathrm{C}$ & Cold Water & 15 & 91.91 & 51.5 \\
\hline $825^{\circ} \mathrm{C}$ & Cold Water & 15 & 92.91 & 55.46 \\
\hline $850^{\circ} \mathrm{C}$ & Cold Water & 15 & 93.5 & 57.67 \\
\hline $800^{\circ} \mathrm{C}$ & Cold Water & 20 & 89.5 & 41.87 \\
\hline $825^{\circ} \mathrm{C}$ & Cold Water & 20 & 92.58 & 44.95 \\
\hline
\end{tabular}




\begin{tabular}{|l|l|l|l|l|}
\hline $850^{\circ} \mathrm{C}$ & Cold Water & 20 & 93.916 & 47.5 \\
\hline
\end{tabular}

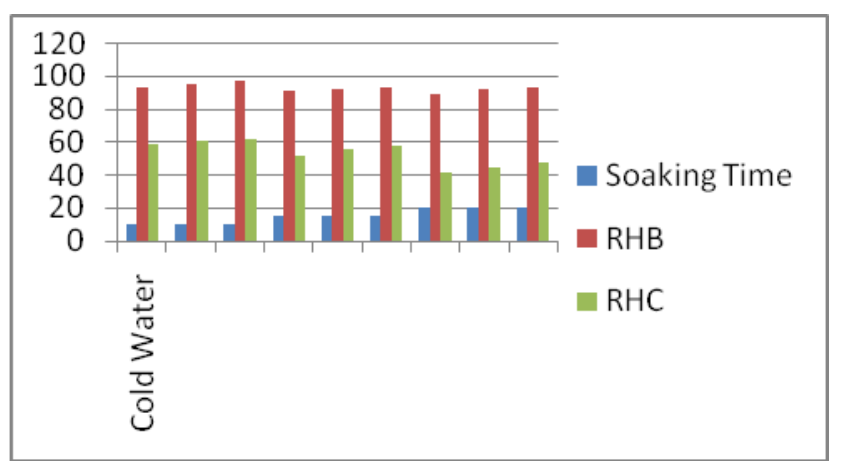

Fig.20 Graph of hardness for different hardening temperature in cold water for different soaking time

Table 3. Hardness Properties For Samples Subjected hardening temperature

\begin{tabular}{|c|c|c|c|c|}
\hline $\begin{array}{c}\text { Hardening } \\
\text { Temperature }\end{array}$ & $\begin{array}{c}\text { Quenching } \\
\text { Media }\end{array}$ & $\begin{array}{c}\text { Soaking } \\
\text { Time }\end{array}$ & RHB & RHC \\
\hline $800^{\circ} \mathrm{C}$ & Hot water & 10 & 85.25 & 33.75 \\
\hline $825^{\circ} \mathrm{C}$ & Hot water & 10 & 87.67 & 35.57 \\
\hline $850^{\circ} \mathrm{C}$ & Hot water & 10 & 89.5 & 37.25 \\
\hline $800^{\circ} \mathrm{C}$ & Hot water & 15 & 80.56 & 28.67 \\
\hline $825^{\circ} \mathrm{C}$ & Hot water & 15 & 82.25 & 30.5 \\
\hline $850^{\circ} \mathrm{C}$ & Hot water & 15 & 84.5 & 32.75 \\
\hline $800^{\circ} \mathrm{C}$ & Hot water & 20 & 76.5 & 25.83 \\
\hline $825^{\circ} \mathrm{C}$ & Hot water & 20 & 80.67 & 27.95 \\
\hline $850^{\circ} \mathrm{C}$ & Hot water & 20 & 82.58 & 29.83 \\
\hline
\end{tabular}

Table 4. Hardness Properties For Samples Subjected hardening

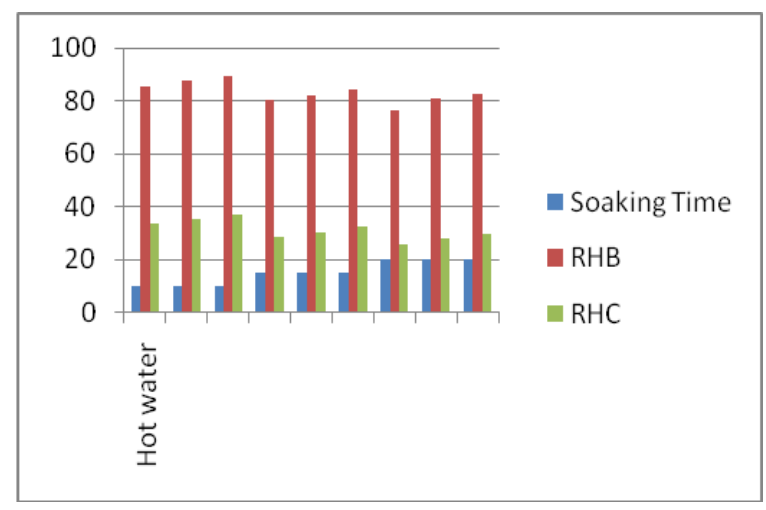

Fig.21 Graph of hardness for different hardening temperature in hot water for different soaking time

\begin{tabular}{|c|c|c|c|c|}
\hline $\begin{array}{c}\text { Hardening } \\
\text { Temperature }\end{array}$ & $\begin{array}{c}\text { Quenching } \\
\text { Media }\end{array}$ & $\begin{array}{c}\text { Soaking } \\
\text { Time }\end{array}$ & RHB & RHC \\
\hline & & & & \\
\hline $800^{\circ} \mathrm{C}$ & Oil & 10 & 82.33 & 20.58 \\
\hline $825^{\circ} \mathrm{C}$ & Oil & 10 & 83.67 & 21.23 \\
\hline $850^{\circ} \mathrm{C}$ & Oil & 10 & 85.5 & 22.55 \\
\hline $800^{\circ} \mathrm{C}$ & Oil & 15 & 80.67 & 18.69 \\
\hline $825^{\circ} \mathrm{C}$ & Oil & 15 & 81.5 & 20.03 \\
\hline $850^{\circ} \mathrm{C}$ & Oil & 15 & 83.67 & 21.75 \\
\hline $800^{\circ} \mathrm{C}$ & Oil & 20 & 78.86 & 14.25 \\
\hline $825^{\circ} \mathrm{C}$ & Oil & 20 & 80.75 & 18.45 \\
\hline $850^{\circ} \mathrm{C}$ & Oil & 20 & 81.5 & 20.01 \\
\hline
\end{tabular}


ELK

Asia Pacific Journals

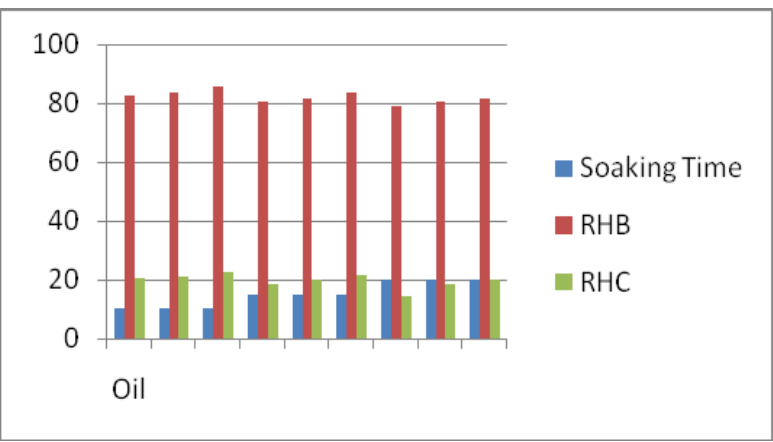

Fig.22 Graph of hardness for different hardening temperature in oil for different soaking time

Table 5. Heat treatment conditions for full annealing process for AISI 1050 Carbon steel-

\begin{tabular}{|l|l|l|l|}
\hline $\begin{array}{l}\text { Full } \\
\text { annealing }\end{array}$ & $\begin{array}{l}\text { Soaking } \\
\text { time }\end{array}$ & Hardness(RHB) & $\begin{array}{l}\text { Quenching } \\
\text { medium }\end{array}$ \\
\hline 800 & 10 & 56.68 & $\begin{array}{l}\text { Furnace } \\
\text { cooling }\end{array}$ \\
\hline 825 & 15 & 57.74 & $\begin{array}{l}\text { Furnace } \\
\text { cooling }\end{array}$ \\
\hline 850 & 20 & 58.02 & $\begin{array}{l}\text { Furnace } \\
\text { cooling }\end{array}$ \\
\hline
\end{tabular}

Table 6. Heat treatment condition for sub critical annealing process for AISI 1050 Carbon steel-

\begin{tabular}{|l|l|l|l|}
\hline $\begin{array}{l}\text { Sub- } \\
\text { critical } \\
\text { Annealing }\end{array}$ & $\begin{array}{l}\text { Soaking } \\
\text { time }\end{array}$ & Hardness(RHB) & $\begin{array}{l}\text { Quenching } \\
\text { medium }\end{array}$ \\
\hline 675 & 15 & 76.44 & $\begin{array}{l}\text { Furnace } \\
\text { cooling }\end{array}$ \\
\hline 700 & 20 & 69.65 & $\begin{array}{l}\text { Furnace } \\
\text { cooling }\end{array}$ \\
\hline
\end{tabular}

Table 7. Heat treatment conditions for normalizing process for AISI 1050 Carbon Steel-

\begin{tabular}{|l|l|l|l|}
\hline Normalizing & $\begin{array}{l}\text { Soaking } \\
\text { time }\end{array}$ & $\begin{array}{l}\text { Hardness } \\
\text { (RHB) }\end{array}$ & $\begin{array}{l}\text { Quenching } \\
\text { medium }\end{array}$ \\
\hline 800 & 10 & 60.124 & Air cooling \\
\hline 825 & 15 & 64.828 & Air cooling \\
\hline 850 & 20 & 67.332 & Air cooling \\
\hline
\end{tabular}

ELK Asia Pacific Journals - Special Issue

ISBN: 978-81-930411-4-7

\section{Conclusions}

i. The micro structural characteristics of these steels were parameterized by the pearlite volume (dark region) fraction.

ii. The percentage of pearlite changes with change in carbon content of steels.

iii. The hardness is strongly influenced by the temperature and time.

iv. The value of hardness decreases with retention of samples in the furnace for a longer period.

v. For AISI 1050 steels higher hardness value have been obtained when quenched in cold water and lowest hardness value have been obtained when quenched in vegetable oil.

vi. The microstructure of AISI 1050 carbon steel in case of normalizing process is pearlite.

vii. The microstructure of AISI 1050 Carbon steel in case of annealing is coarse pearlite.

\section{References}

[1] G.Krauss, Steels: Heat Treatment and processing principles, ASM International, OH, USA, 1989.

[2] OJAY $1^{\text {st }}$ publication PDF- Effect of Heat Treatment on the mechanical properties of rolled medium carbon steel.

[3] Adan,Calik.Effect of Cooling rate on Hardness and Microstructure of AISI 1020,AISI 1040 and AISI 1060 Steels. Int J of Physics Sciences, vol.4(9),

[4] Ashish Bhateja, A. V. (2012). Study the Effect on the Hardness of three Sample Grades of Tool Steel i.e. EN-31, EN-8, and D3 after heat treatment Processes Such As Annealing, Normalizing, and Hardening \& Tempering. The International Journal of Engineering and Science (IJES), Vol.1 No.2, 253-259.

[5] Atik, E. Y. (March 2003, Vol.36). The effects of conventional heat treatment and boronizing on abrasive wear and corrosion of SAE 1010, SAE 1040, D2 and 304 steels. Tribology International, 155-161.

[6] Demirkol, K. G. (1999). Effect of case depth on fatigue performance of AISI 8620 carburized steel. International Journal of Fatigue, Vol. 21, 207-212.

[7] Enver Atık, U. Y. (2003). The effects of conventional heat treatment and boronizing on abrasive wear and corrosion of SAE 1010, SAE 1040, D2 and 304 steels. Tribology International, Vol.36, 155-161. 


\section{(2) \\ ELK \\ Asia Pacific Journals}

[8] A. (2013). Heat Treatment ofEN-8 Steel Casting Samples. India: metalworld.

[9] R. Balasubramaniam, (2010). Callister's Materials Science and Engineering. India: Wiley India Pvt. Ltd.

[10] T. V. Rajan, C. S. (2011). Heat Treatment Principles and Techniques. India: PHI.

[11] Hanbook of Engineering Tool \& Alloy Steel Manual.

[12] Design Data Handbook by K.Mahadevan \& K.Balaveera Reddy 